\title{
Correction to: ARE/SUZ12 dual specifically- regulated adenoviral TK/GCV system for CML blast crisis cells
}

Bailing $\mathrm{Zu}^{1 \dagger}, \mathrm{Yi} \mathrm{Shi}^{2 \dagger}, \mathrm{Min} \mathrm{Xu}^{1}$, Guoling You${ }^{3}$, Zhenglan Huang ${ }^{1}$, Miao Gao ${ }^{1}$ and Wenli Feng ${ }^{{ }^{*}}$

Correction to: J Exp Clin Cancer Res 34, 56 (2015)
https://doi.org/10.1186/s13046-015-0139-4

Following publication of the original article [1], the authors identified a minor error in Figure 4, specifically:

- Fig. 4: incorrect immunofluorescent staining image used to represent KCL22 Ad-empty control ( $2^{\text {nd }}$ row, $2^{\text {nd }}$ column); the image has been replaced with the correct image

The corrected figure is given here. The correction does not have any effect on the final conclusions of the paper.
Published online: 09 February 2022

\section{Reference}

1. Zu B, Shi Y, Xu M, et al. ARE/SUZ12 dual specifically-regulated adenoviral TK/GCV system for CML blast crisis cells. J Exp Clin Cancer Res. 2015;34:56 https://doi.org/10.1186/s13046-015-0139-4.

\section{Author details}

'Department of Clinical Hematology, Key Laboratory of Laboratory Medical

Diagnostics of Ministry of Education, Chongqing Medical University, No.1, Yixueyuan Road, Chongqing 400016, People's Republic of China. ${ }^{2}$ Department of Clinical Laboratory, Shanghai Pudong Hospital, Fudan University Pudong Medical Center, Shanghai, China. ${ }^{3}$ Department of Clinical Laboratory, Shanghai Children's Medical Center, Shanghai Jiaotong University School of Medicine, Shanghai, China.

*Correspondence: fengwlcamu@sina.com

${ }^{\dagger}$ Bailing Zu and Yi Shi contributed equally to this work.

1 Department of Clinical Hematology, Key Laboratory of Laboratory

Medical Diagnostics of Ministry of Education, Chongqing Medical

University, No.1, Yixueyuan Road, Chongqing 400016, People's Republic of China

Full list of author information is available at the end of the article to the material. If material is not included in the article's Creative Commons licence and your intended use is not permitted by statutory regulation or exceeds the permitted use, you will need to obtain permission directly from the copyright holder. To view a copy of this licence, visit http://creativecommons.org/licenses/by/4.0/. The Creative Commons Public Domain Dedication waiver (http://creativeco mmons.org/publicdomain/zero/1.0/) applies to the data made available in this article, unless otherwise stated in a credit line to the data. 


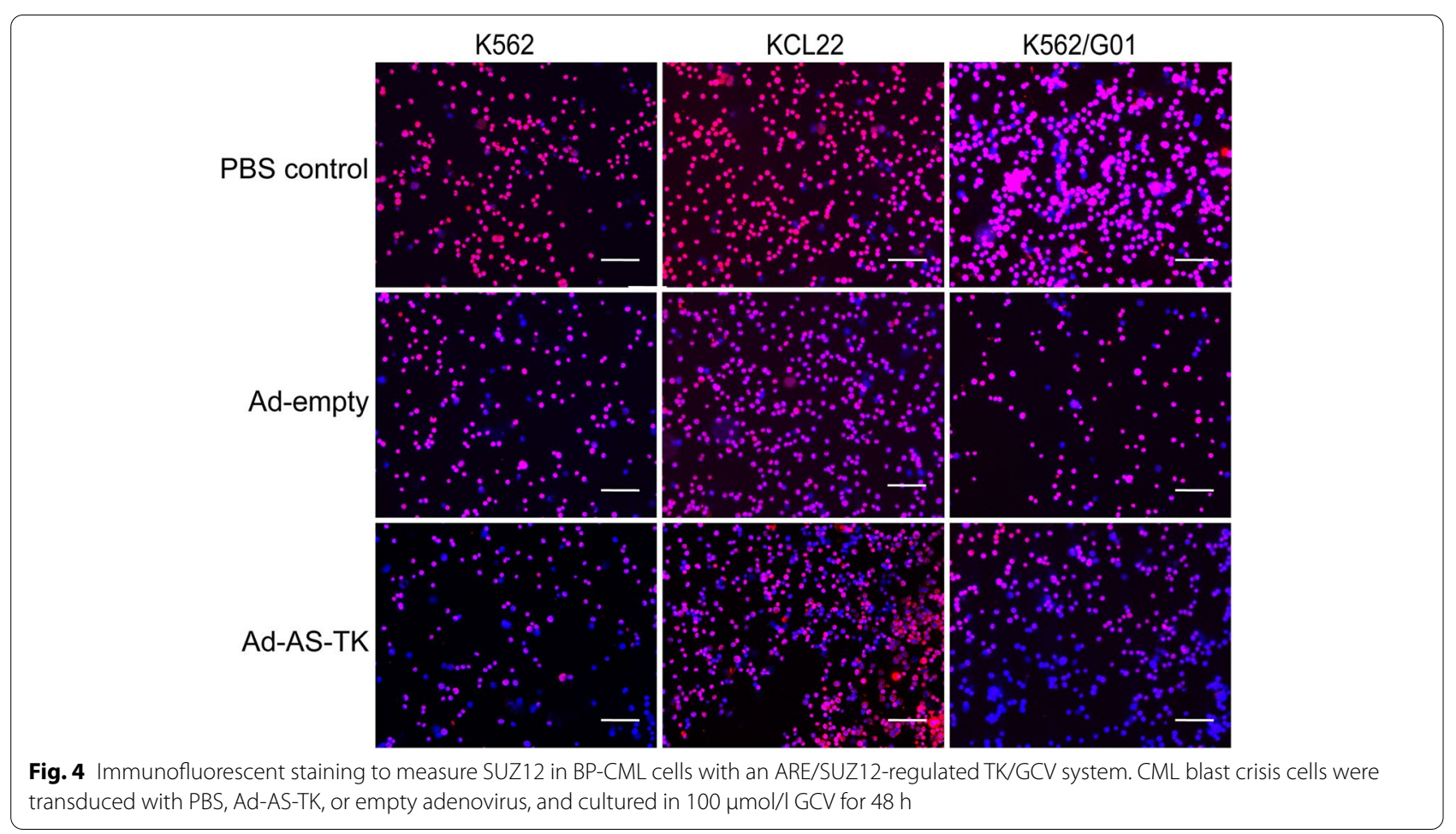

